\title{
Budd-Chiari syndrome in a patient with ulcerative colitis
}

\author{
Gopal Krishana Bohra, ${ }^{1}$ Vivek Chhabra, ${ }^{1}$ Naresh Midha, ${ }^{1}$ Binit Sureka
}

${ }^{1}$ Department of Medicine, All India Institute of Medical Science, Jodhpur, Rajasthan, India

${ }^{2}$ Department of Radiodiagnosis, All India Institute of Medical Sciences, Jodhpur, Rajasthan, India

\section{Correspondence to}

Dr Gopal Krishana Bohra, gopalbohra17@gmail.com

Accepted 19 January 2018

\section{SUMMARY}

We report a case of 26-year-old man who was admitted on our ward for the evaluation of ascites. He was a known case of inflammatory bowel disease(ulcerative colitis) and was on regular mesalamine therapy. On evaluation, he was having high serum ascites albumin gradient. CT scan of the abdomen revealed features of portal hypertension and non-visualisation of right and middle hepatic veins along with thrombus in inferior vena cava, suggesting a diagnosis of BuddChiari syndrome (BCS). There are only few case reports available showing association of BCS with UC. Hence, we are reporting this interesting and rare case.

\section{BACKGROUND}

Inflammatory bowel disease (IBD) is a chronic immune-related disorder of the gastrointestinal

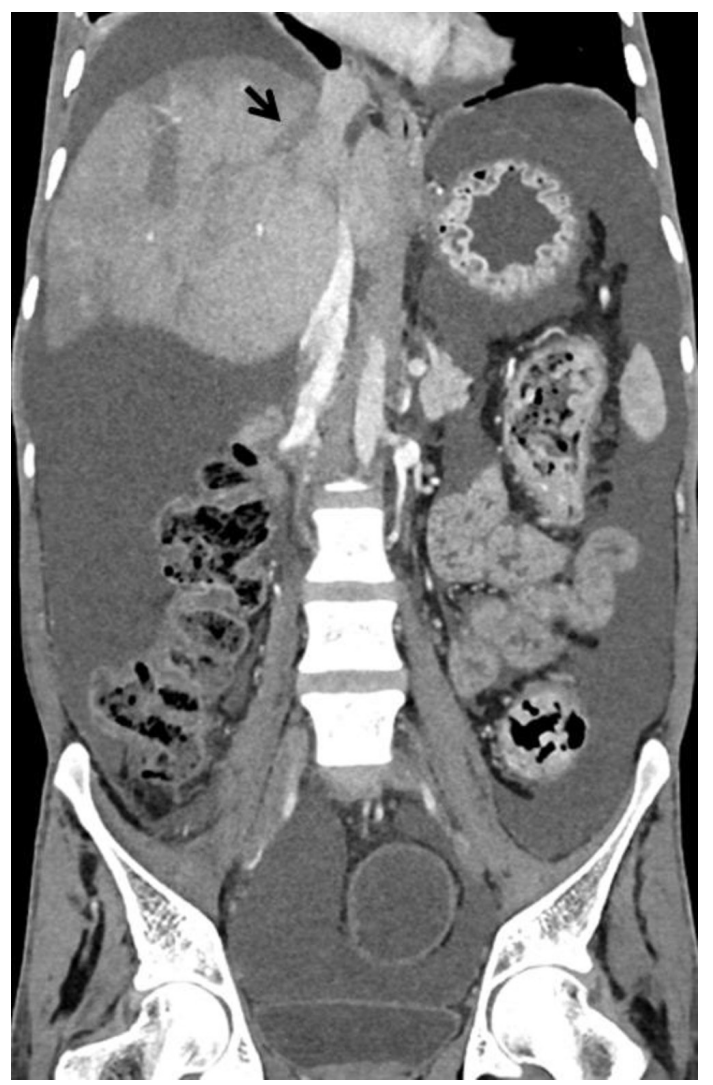

Figure 1 Coronal-reformatted contrast-enhanced CT hepatic venous phase image showing differential enhancement of the liver with thrombosed hepatic vein (black arrow) and gross ascites.

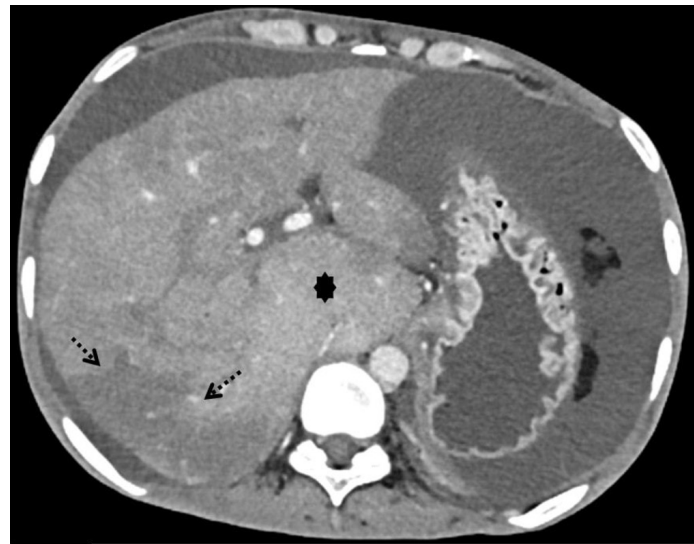

Figure 2 Axial contrast-enhanced CT image showing differential enhancement of the liver (dashed arrows) with caudate lobe hypertrophy (asterisk) and gross ascites.

(GI) tract. Disorders of the liver and biliary tract can occur as extraintestinal manifestations of IBD. Budd-Chiari syndrome (BCS) has been described as a rare complication of ulcerative colitis (UC). Patients with UC have a greater tendency to venous thrombosis presenting both clinically and found incidentally at autopsy. The incidence of venous thrombosis in UC was found to be $39 \%$ in one autopsy study, ${ }^{1}$ but hepatic vein thrombosis in BCS has been reported only as a rare extraintestinal complication of UC.

\section{CASE PRESENTATION}

A 26-year-old man was admitted to our hospital with chief complaints of abdominal distension from the last 15 days. There was no history of fever, yellowness of sclera, upper GI bleeding or altered behaviour. There was significant history of UC diagnosed 5 years ago when the patient underwent colonoscopy for chronic bloody diarrhoea. Colonoscopy was suggestive of pancolitis. Diagnosis of ulcerative colitis was confirmed on histopathology. Patient was on regular mesalamine therapy with a history of acute flare-up only once during 5 years. During this presentation, there was no history of worsening of symptoms of UC. There is no history of any indigenous drug intake. Patient was haemodynamically stable and afebrile. There was no icterus or lymphadenopathy. There was no stigma of chronic liver disease. There was temporal loss of fat along with white nails. Per abdomen examination revealed shifting dullness and spleen was 


\begin{tabular}{|c|c|}
\hline Haemoglobin level & $13 \mathrm{~g} / \mathrm{dL}(14-18 \mathrm{~g} / \mathrm{dL})$ \\
\hline Total leucocyte count & $5.96 \times 10^{9} / \mathrm{L}\left(3.5-12.0 \times 10^{9} / \mathrm{L}\right)$ \\
\hline Platelets & $446 \times 10^{9} / \mathrm{L}\left(150-400 \times 10^{9} / \mathrm{L}\right)$ \\
\hline $\begin{array}{l}\text { High sensitivity } \\
\text { C reactive protein }\end{array}$ & $25.89 \mathrm{mg} / \mathrm{L}(<3 \mathrm{mg} / \mathrm{L})$ \\
\hline Liver function tests & $\begin{array}{l}\text { SGPT-31 IU/L (5-35 IU/L), SGOT-30 IU/L (7-40 IU/L) } \\
\text { Total bilirubin-0.50 mg/dL ( } 0.2-1.3 \mathrm{mg} / \mathrm{dL}) \\
\text { Direct bilirubin-0.11 mg/dL (0-0.3 mg/dL) } \\
\text { Alkaline Phosphatase(ALP) - } 248 \mathrm{IU} / \mathrm{L}(40-150 \mathrm{IU} / \mathrm{L})\end{array}$ \\
\hline $\begin{array}{l}\text { Serum albumin } \\
\text { Serum globulin }\end{array}$ & $\begin{array}{l}22.1 \mathrm{~g} / \mathrm{L}(35-40 \mathrm{~g} / \mathrm{L}) \\
27.5 \mathrm{~g} / \mathrm{L}(20-35 \mathrm{~g} / \mathrm{L})\end{array}$ \\
\hline Kidney function tests & $\begin{array}{l}\text { Blood urea-2.33 mmol/L }(2.9-8.2 \mathrm{mmol} / \mathrm{L}) \\
\text { Serum creatinine- } 33.59 \mu \mathrm{mol} / \mathrm{L}(50-110 \mu \mathrm{mol} / \mathrm{L})\end{array}$ \\
\hline $\begin{array}{l}\text { Sodium } \\
\text { Potassium }\end{array}$ & $\begin{array}{l}135 \mathrm{mmol} / \mathrm{L}(135-145 \mathrm{mmol} / \mathrm{L}) \\
3.54 \mathrm{mmol} / \mathrm{L}(3.5-5.1 \mathrm{mmol} / \mathrm{L})\end{array}$ \\
\hline Anti-hepatitis $C$ virus rapid test & Non-reactive \\
\hline $\begin{array}{l}\text { Hepatitis B surface antigen rapid test } \\
\text { (for hepatitis B) }\end{array}$ & Negative \\
\hline HIV rapid test & Non-reactive \\
\hline Activated partial thromboplastin time & $34 s(25-40 s)$ \\
\hline $\begin{array}{l}\text { Prothrombin time } \\
\text { International normalised ratio }\end{array}$ & $\begin{array}{l}12.4 s(9-13 s) \\
1.03\end{array}$ \\
\hline $\begin{array}{l}\text { Ascitic fluid-microscopic } \\
\text { examination }\end{array}$ & $\begin{array}{l}\text { Neubauer chamber count-20 cells } / \mathrm{mm}^{3} \\
\text { Mostly lymphocytes }\end{array}$ \\
\hline Serum ascites albumin gradient & 1.21 \\
\hline
\end{tabular}

palpable $2 \mathrm{~cm}$ below the left costal margin. The patient was further evaluated with biochemical and haematological investigations and ascitic fluid analysis (table 1). Based on investigations and the fact that there was high serum ascites albumin gradient, the patient was further evaluated.

Ultrasonography of the abdomen with venous doppler was done which showed fatty liver with moderate ascites and non-visualisation of right and middle hepatic veins. Further CT abdomen was done which confirmed the findings and showed thrombus in inferior vena cava (IVC) and hepatic veins suggestive of BCS (figures 1-3). Based on clinical and radiological findings, final diagnosis of UC (mild) with BCS was made. Haematological parameters, prothrombin time and activated partial thromboplastin time of the patient were normal. However, extensive coagulation profile of the patient could not be done due to financial constraints. Patient was started on oral anticoagulation

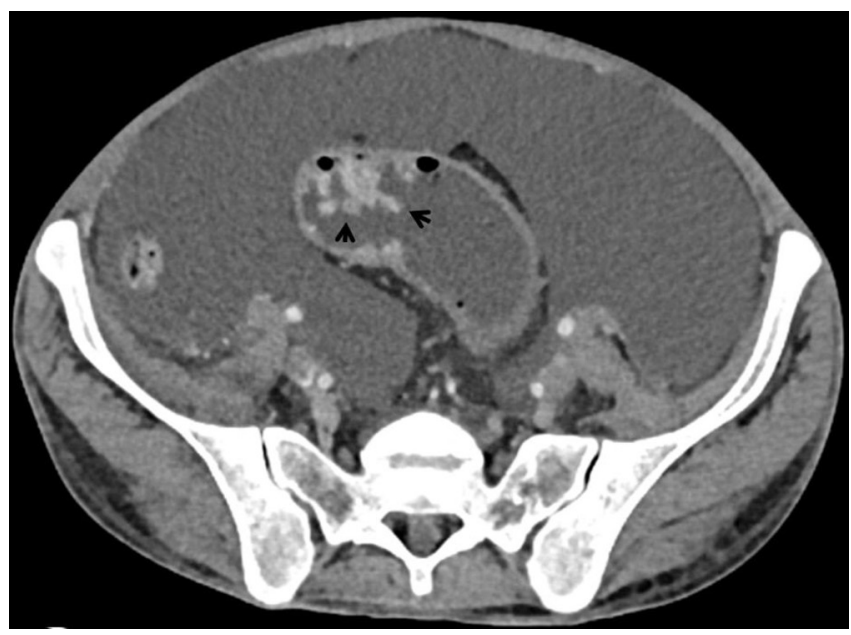

Figure 3 Axial contrast-enhanced CT image showing thickening of sigmoid colon and pseudopolyp formation (arrows) with fat stranding in surrounding region with gross ascites. therapy (acitrom :composition formula of acenocoumarol)) and mesalamine was continued. The patient was also started on spironolactone, propranolol, and given advice on low salt intake and was discharged. The patient was advised follow-up and international normalised ratio (INR) monitoring.

\section{OUTCOME AND FOLLOW-UP}

The patient had come for follow-up after 3 months. The patient is doing well on oral anticoagulants and has improved symptomatically. No untoward side effect of anticoagulants were noticed till now.

\section{DISCUSSION}

In BCS, there is interruption or diminution of the normal blood flow out of the liver resulting in venous congestion. ${ }^{2}$ BCS can present in an acute, subacute or chronic form. In an acute form, there is sudden onset of abdominal pain, distention, jaundice, hepatomegaly, ascites and oedema. ${ }^{3}$ Acute presentation can lead to acute fulminant hepatic failure. The chronic presentations are similar to the acute form but developing much more slowly over the months or years. Also, there is presence of visibly dilated abdominal veins and splenomegaly without encephalopathy.

Hepatic complications of UC include fatty liver, pericholangitis and sclerosing cholangitis, but UC as a precipitant of BCS in the absence of other inheritable causes has been rarely reported. There is increased risk of venous thromboembolism in patients with UC. Moreover, the risk is eight times higher during a flare-up. ${ }^{4}$ There is also increased risk of arterial thromboembolic events. ${ }^{5}$ The incidence of venous thrombosis in UC was found to be $39 \%$ in autopsy studies, but hepatic vein or inferior vena cava thrombosis is a rare extraintestinal complication of UC. ${ }^{1}$ There are few case reports available suggesting the association between IBD and BCS (table 2).

The exact reason for this increased incidence of thromboembolic events in IBD is, however, not completely understood. No identifiable reason has been found in approximately half of the patients with IBD who develop thromboembolism which reinforces the hypothesis that IBD per se is a risk factor for thrombosis. ${ }^{6}$ There is aberrant behaviour of platelets in both Crohn's disease and UC. Thrombocytosis frequently occurs during the active phase of IBD. There is a high correlation between platelet number and disease activity. ${ }^{7}$ It is likely to be a non-specific response to inflammation; however, the exact reason is still not very well understood. Also, there is lack of sufficient evidence which solidify the association between thrombocytosis and activity of IBD. The platelet count in our patient was normal. This may be due to the fact that the patient was not in an acute flare-up of the UC.

Therapeutic options for BCS (with IBD) are varied and depend on clinical presentation. Anticoagulation should be initiated immediately and continued for life unless contraindicated. An extensive work-up for secondary causes of hypercoagulability should be performed. In symptomatic patients, percutaneous angiography may be done to look for venous obstruction and stents may be placed if necessary. Transjugular intrahepatic portosystemic shunt (TIPS) is reserved for those not improving with anticoagulation and who have failed other management strategies. Liver transplantation should be considered for fulminant liver failure or failure to respond to TIPS. Medical therapy alone is recommended in patients without evidence of ongoing hepatic necrosis. ${ }^{8}$ 
Table 2 Review of literature for association between inflammatory bowel disease (IBD) and Budd-Chiari syndrome

\begin{tabular}{|c|c|c|}
\hline $\begin{array}{l}\text { Authors, } \\
\text { reference no }\end{array}$ & Patient(s) profile & Remarks \\
\hline Maccini et al ${ }^{11}$ & 35-year-old woman & First reported case of Crohn's disease presenting as BCS \\
\hline Witteman et al ${ }^{12}$ & 16-year-old woman & $\begin{array}{l}\text { Patient with Crohn's disease developed hepatic vein thrombosis possibly due to hypercoagulability during exacerbation of her } \\
\text { disease. }\end{array}$ \\
\hline Rahhal et al ${ }^{14}$ & 14-year-old woman & First reported case of bowel ischaemia secondary to vascular thrombosis in paediatric patients who have IBD. \\
\hline Park et a $\left.\right|^{15}$ & 27-year-old woman & There was simultaneous BCS and superior mesenteric vein thrombosis in a patient with UC. \\
\hline Dacha et $a l^{16}$ & 27-year-old woman & $\begin{array}{l}\text { This case highlighted the potential for thrombosis at unusual sites in patients with UC without having classical coagulation } \\
\text { abnormalities. }\end{array}$ \\
\hline Yılmaz et $a l^{17}$ & 19-year-old man & There was simultaneous presentation of UC and BCS in the patient. \\
\hline
\end{tabular}

This case, along with the previous reports outlined above, recapitulates the need for a high level of suspicion for BCS in patients with IBD.

\section{Learning points}

- Inflammatory bowel disease (IBD) patients can have varied range of intestinal and extraintestinal manifestations.

- Patients with IBD are at increased risk of venous and arterial thrombosis.

- Hepatic vein or inferior vena cava thrombosis is a rare extraintestinal complication of ulcerative colitis.

- There should be a high level of suspicion for Budd-Chiari syndrome in patients with IBD presenting with ascites.

Contributors GKB has produced the report and literature review. VC assisted in the production of the report, the literature review and was also involved in the care of the patient. NM oversaw the creation of the report and was additionally involved in the care of the patient. SB did the radiological investigations of the patient and provided valuable insight into the case.

Competing interests None declared.

Patient consent Obtained.

Provenance and peer review Not commissioned; externally peer reviewed.

(c) BMJ Publishing Group Ltd (unless otherwise stated in the text of the article) 2018. All rights reserved. No commercial use is permitted unless otherwise expressly granted.

\section{REFERENCES}

1 Sloan WP, Bargen JA, Gage RB. Life histories of patients with chronic ulcerative colitis: a review of 2,000 cases. Gastroenterology 1968;54(4):819-22.
2 Valla DC. Budd-chiari syndrome and veno-occlusive disease/sinusoidal obstruction syndrome. Gut 2008;57:1469-78.

3 Gentil-Kocher S, Bernard O, Brunelle F, et al. Budd-chiari syndrome in children: report of 22 cases. J Pediatr 1988;113:30-8.

4 Spina L, Saibeni S, Battaglioli T, et al. Thrombosis in inflammatory bowel diseases: role of inherited thrombophilia. Am J Gastroenterol 2005;100:2036-41.

$5 \mathrm{Ha} \mathrm{C}$, Magowan S, Accortt NA, et al. Risk of arterial thrombotic events in inflammatory bowel disease. Am J Gastroenterol 2009;104:1445-51.

6 Jackson LM, O'Gorman PJ, O'Connell J, et al. Thrombosis in inflammatory bowel disease: clinical setting, procoagulant profile and factor V Leiden. QJM 1997:90:183-8.

7 Chiarantini E, Valanzano R, Liotta AA, et al. Persistence of hemostatic alterations in patients affected by crohn's disease after bowel surgery. Thromb Res 1997;87:539-46.

8 Menon KV, Shah V, Kamath PS. The Budd-Chiari syndrome. N Eng/ J Med 2004:350:578-85.

9 Chesner IM, Muller S, Newman J. Ulcerative colitis complicated by budd-chiari syndrome. Gut 1986:27:1096-100.

10 Brinson RR, Curtis WD, Schuman BM, et al. Recovery from hepatic vein thrombosis (budd-chiari syndrome) complicating ulcerative colitis. Dig Dis Sci 1988;33:1615-20.

11 Maccini DM, Berg JC, Bell GA. Budd-chiari syndrome and crohn's disease. An unreported association. Dig Dis Sci 1989:34:1933-6.

12 Witteman BJ, Weterman IT, Griffioen G, et al. [Intestinal obstruction caused by nonabsorbable tablets and budd-chiari syndrome in a patient with crohn's disease]. Ned Tijdschr Geneeskd 1991;135:766-9.

13 Kraut J, Berman JH, Gunasekaran TS, et al. Hepatic vein thrombosis (budd-chiari syndrome) in an adolescent with ulcerative colitis. J Pediatr Gastroenterol Nutr 1997;25:417-20.

14 Rahhal RM, Pashankar DS, Bishop WP. Ulcerative colitis complicated by ischemic colitis and budd chiari syndrome. J Pediatr Gastroenterol Nutr 2005;40:94-7.

15. Park SY, Kim YJ, Park IH, et al. [A case of budd-chiari syndrome and superior mesenteric vein thrombosis in ulcerative colitis]. Korean I Gastroenterol 2005;45:201-5.

16 Dacha S, Devidi M, Osmundson E. Budd-chiari syndrome in a patient with ulcerative colitis and no inherited coagulopathy. World J Hepatol 2011;3:164.

17 YIlmaz B, Köklü S, Bayraktar Y. Ulcerative colitis presenting with budd-chiari syndrome. J Crohns Colitis 2013;7:e74-e75.

Copyright 2018 BMJ Publishing Group. All rights reserved. For permission to reuse any of this content visit

http://group.bmj.com/group/rights-licensing/permissions.

BMJ Case Report Fellows may re-use this article for personal use and teaching without any further permission.

Become a Fellow of BMJ Case Reports today and you can:

- Submit as many cases as you like

- Enjoy fast sympathetic peer review and rapid publication of accepted articles

- Access all the published articles

- Re-use any of the published material for personal use and teaching without further permission

For information on Institutional Fellowships contact consortiasales@bmjgroup.com

Visit casereports.bmj.com for more articles like this and to become a Fellow 